\title{
Hydroxyzine Hydrochloride
}

National Cancer Institute

\section{Source}

National Cancer Institute. Hydroxyzine Hydrochloride. NCI Thesaurus. Code C47559.

The hydrochloride salt form of hydroxyzine, a piperazine histamine $\mathrm{H} 1$-receptor antagonist with anti-allergic, antispasmodic, sedative, anti-emetic and anti-anxiety properties. Hydroxyzine hydrochloride blocks the $\mathrm{H} 1$ histamine receptor and prevents the symptoms that are caused by histamine activity on capillaries, bronchial smooth muscle, and gastrointestinal smooth muscle, including vasodilatation, increased capillary permeability, bronchoconstriction, and spasmodic contraction of gastrointestinal smooth muscle. In addition, hydroxyzine hydrochloride crosses the blood-brain barrier and acts on the histamine $\mathrm{H} 1$-receptors in the central nervous system. ( $\mathrm{NCI05)}$ 